\title{
Kopy Luwak: a conservation strategy for global market
}

Aluisius Hery Pratono and Irzameingindra Putri Radjamin

Aluisius Hery Pratono and Irzameingindra Putri Radjamin are based in the Faculty of Business and Economics, University of Surabaya, Surabaya, Indonesia.
It was May 2012 that Mr Erwan, the new CEO of PT Perkebunan Nusantara XII (PTPN XII) put forward a vision for the plantation company. During this initial tenure, he was fully aware that one of the company's products, Kopi Luwak, was becoming popular:

[.. . I I am expecting that Kopi Luwak will bring about a revolution in the Indonesian coffee industry, which is represented by our company. This company manages to meet the emerging demand [...].

However, the company faced challenges regarding the international market and there were many nagging questions that came to his mind. First, how could the company convince the market that Kopi Luwak is the best coffee in the world? How could the company fulfill the demand from a long queue of customers? How could the company meet the demand and satisfy the conservation needs for a wild animal, the "luwak"? 